\title{
The Sports mental toughness questionnaire (SMTQ): A psychometric evaluation of the Turkish version
}

\author{
Dotazník sportovní psychické odolnosti (SMTQ): \\ psychometrické hodnocení turecké verze
}

\author{
Bülent Okan Miçooğulları
}

Physical Education \& Sports Department, Nevşehir Hacı Bektaş Veli University, Nevşehir-TURKEY

\begin{abstract}
The objective of this study was to adapt the Sports Mental Toughness Questionnaire (SMTQ) for use in Turkey, and to test its reliability and validity. With a sample of 184 males (mean \pm s: age $24.22 \pm 3.01$ years) and 153 females (mean \pm s: age $21.54 \pm 3.82$ years) total 337 athletes (mean $\pm s$ : age $21.76 \pm 4.2$ years) drawn from 20 sport classifications, confirmatory factor analysis technique to evaluate the psychometric properties of the sport mental toughness questionnaire. Athletes completed 14 items sport mental toughness questionnaire was applied to all volunteered participants. Afterwards, Confirmatory Factor Analysis was conducted by Analysis Moments of Structures 18. Comparative fit index, non-normed fit index and root mean square error of approximation were used to check if the model fit the data. Chi-square/degrees of freedom ratio was found as ( $\left.X^{2} / d f\right) 1.46$. The other parameters were determined as root mean square error of approximation $=0.74$, non-normed fit index $=0.90$, and comparative fit index $=0.90$. The confirmatory factor analysis results supported the three-factor structure and indicated proper models should include correlations among the three factors. Internal consistency estimates ranged from 0.69 to 0.78 and were consistent with values reported by previous studies. Based on these findings, "Sports Mental Toughness Questionnaire" was found to be a valid and reliable instrument.
\end{abstract}

\begin{abstract}
Abstrakt
Cílem této studie bylo prizpưsobit dotazník sportovní psychické odolnosti (SMTQ) pro použití v Turecku a ověrit jeho spolehlivost a platnost. K vyhodnocení psychometrických vlastností pomocí dotazníku o sportovní psychické odolnosti byl použit vzorek 184 mužů (věkový průměr 24,22 $\pm 3,01$ let) a 153 žen (věkový průměr $21,54 \pm 3,82$ let) tj. celkem 337 sportovců (průměr \pm s: věk 21,76 $\pm 4,2$ let). Sportovci, dobrovolní účastníci výzkumu, odpovídali na 14 dotazů dotazníku psychické odolnosti. Poté byla provedena konfirmační faktorová analýza. Pro porovnání, zda model odpovídá datům, byl použit porovnávací index zdatnosti, index nestandardní zdatnosti a střední kvadratická chyba aproximace. Poměr chi-druhá mocnina / stupně volnosti byl určen jako ( $\left.X^{2} / d f\right)$ 1,46. Ostatní parametry byly určeny jako střední kvadratická chyba aproximace $=0,74$, index nestandardní zdatnost $i=0,90$ a srovnávací index zdatnosti $=0,90$. Výsledky konfirmační faktorové analýzy byly $v$ souladu s tř́faktorovou strukturou a ukázaly, že správné modely by měly zahrnovat korelace mezi třemi faktory. Odhady interní konzistence se pohybovaly $v$ rozmezí od 0,69 do 0,78 a odpovídaly hodnotám uvedeným $v$ predchozích studiích. Na základě těchto zjištění bylo zjištěno, že dotazník "Sportovní duševní odolnosti“ je platným a spolehlivým nástrojem.
\end{abstract}

Keywords: Sport Psychology, Mental Preparation, Confirmatory factor analysis.

Klíčová slova: Sportovní psychologie, Mentální příprava, Konfirmační faktorová analýza. 


\section{INTRODUCTION}

There is considerable number of studies on the psychological parameters that affecting athletes' sportive achievement and their sport life, one of them is mental toughness (MT). Initially, researchers, who attempted to understand what MT is, collected data that included participant perspectives about this concept and those studies have been conducted across a number of different sports disciplines such as football, rugby, cricket, soccer and basketball (Bull et al., 2005; Golby \& Sheard, 2004; Gucciardi, Gordon, Dimmock, 2009; Newland et al., 2013; Thelwell, Weston $\&$ Greenless, 2005). The analysis of these qualitative studies highlights an important aspect in relation to MT that is the concept is fairly open to individual interpretation. Participants in the studies mentioned above described MT in a number of different ways which indicates that the term can be interpreted differently by individuals depending on different variables such as gender, age group, and culture and situations such as sports performance, being disabled, and breavement. These findings imply that researchers need to be more careful in developing a general definition of the concept. On this basis, analysis of differences and similarities of chronological MT definitions can be helpful to understand and evaluate it better. Based on their findings, Rotella (1998) focused specifically to a competitive game situation definition of MT as; 'It is being more consistent and better than your opponents in remaining determined, focused, confident and in control under pressure' (p. 61). Clough, Earle, \& Sewell (2002); 'Mentally tough individuals tend to be sociable and outgoing; as they are able to remain calm and relaxed, they are competitive in many situations and have lower anxiety levels than others. With a high sense of self-belief and an unshakeable faith that they control their own destiny, these individuals can remain relatively unaffected by competition or adversity' (p. 38). Thelwell, Weston, \& Greenlees (2005); 'Mental toughness is having the natural or developed edge that enables you to: (i) always [emphasis added], cope better than your opponents with the many demands (competition, training, lifestyle) that sport places on a performer; (ii) specifically, be more consistent and better than your opponents in remaining determined, focused, confident, and in control under pressure' (p. 326). Gucciardi, Gordon, \& Dimmock, (2008); 'Mental toughness is a collection of values, attitudes, behaviors, and emotions that enable you to persevere and overcome any obstacle, adversity, or pressure experienced, but also to maintain concentration and motivation when things are going well to consistently achieve your goals' (p. 278). Middleton, Martin \& Marsh (2011); 'Unshakeable perseverance and conviction towards some goal despite pressure or adversity' (p. 94). Clough and Strycharczyk (2012); 'The quality which determines in large part how people deal effectively with challenge, stressors and pressure, respective of prevailing circumstances' ( $\mathrm{p} .1$ ). Hardy, Bell \& Beattie (2014); 'Mental toughness is the ability to achieve personal goals in the face of pressure from a wide range of different stressors' (p. 70). Gucciardi, Hanton, Gordon, Mallett, \& Temby (2015); 'Mental toughness is a personal capacity to produce consistently high levels of subjective (e.g., personal goals or strivings) or objective performance (e.g., sales, race time, GPA) despite everyday challenges and stressors as well as significant adversities' (p. 28). All of these definitions has similarities and differences; the researchers consider that MT is a fairly stable arrangement, although it may change in the face of certain types of experience, this can be named as similarity. However, previous studies have defined MT in relation to others, recent studies results have expanded this phenomenon to include subjective or goal-oriented dimensions, and this could be speculated as differences between definitions.

Mental toughness is the presence of some or the entire collection of experientially developed and inherent values, attitudes, emotions, cognitions, and behaviors that influence the way in which an individual approaches, responds to, and appraises both negatively and positively construed pressures, challenges, and adversities to consistently achieve his or her goals (Coulter, Mallett \& Gucciardi, 2010). 
After theoretical baseline some effort has been devoted to design of a reliable and valid measure of MT in sport. Though attention has been given to the construction of scales measuring the construct, little supporting psychometric evidence is available for them.

Mental Toughness Inventory is a measure of 48 questions, rated as "I strongly agree" and "I strongly disagree" with the five-point Likert scales. The scale has a total score and each subdimension is scored separately as well. The sub-dimensions of the scale are commitment, emotional control, life control, challenge, interpersonal confidence and confidence in abilities. One important point to mention is that there is little scientific study that examines the psychometric properties of this scale. In particular, descriptive and confirmatory factor analysis techniques have been carefully studied to determine the factor structure of the scale. These processes of statistics have been ignored (Clough, Earl \& Sewell, 2002).

The inability of the theoretical sub-structure of the scale brought many questions together.

In 2004, Middleton and colleagues developed the Inventory of Mental Toughness, consisting of 5 items and 12 mental toughness sub-dimensions, after the first work that could be described as a scientific move. When the development of this questionnaire is examined, it is seen that structural validity is improved and the theoretical base has been improved, which was not the case for the previous scale. Regarding this scale, however, the validity of the scale has been tested only on elite athletes at high school level between the ages of 12-19, and this is regarded as a serious limitation on the scale. The psychometric properties of this scale need to be tested on different groups and numbers (Middleton, Martin \& Marsh, 2011).

The Psychological Performance Inventory, which was one of the first studies on the measurement of the psychometric properties of the concept of MT, consisted of 42 questions. This study by Loehr, 1996 included cognitive-behavioral and individual assessment (Loehr, 1996). Although Loehr has provided a convincing discussion platform for the scale, the conceptual and theoretical infrastructure of the scale was not strong. In addition, Loehr did not provide psychometric support for the usability of scale.

In 2007, Golby, Sheard and van Wersch provided a low-level statistical support for the sevenfactor structure of the scale. Golby and colleagues supported their scientific studies by developing an alternative scale to the Psychological performance inventory. Golby et al., at the end of the process, presented a structure with four sub-dimensions consisting of Determination, Self-belief, Positive Cognition and Visualization. It should be noted that, Alternative Psychological Performance Inventory, was encouraging, and convergent validity sufficient, internal consistency was poor. The most important distress related to this scale is that the concept of "control", which is constantly shared in the literature of mental toughness, is evaluated at this scale (Golby, Sheard, \& van Wersch, 2007).

The most recent study to determine the psychometric factors related to that concept is the Mental Toughness in Sports scale of 14 questions made by Sheard, Golby and van Wersch in 2009. This scale also consists of Confidence (6 questions), Constancy (4 items) and Control (4 items) sub-dimensions which are scored with a four point Likert type scale. The authors suggested investigating the structural validity in other groups and at age levels and the effects of different intervention programs on mental toughness (Sheard, Golby, \& van Wersch, 2009).

All statistical and theoretical scientific efforts related with mental toughness revealed that it is a vital component in sport environment. Because of the importance of mental toughness phenomenon; athletes, coaches, chairmen, managers and sport psychologists accepted to have benefits of valid and reliable instruments for evaluating mental toughness. In the lights of all above information aim of the present study was to test psychometric properties of SMTQ-Turkish version on Turkish population. 


\section{METHODOLOGY}

\section{Participants}

The sample of study consisted of 184 males $(24.22 \pm 3.01$ years $)$ and 153 females ( $21.54 \pm 3.82$ years $)$, totally 337 athletes (mean $\pm s$ : age $21.76 \pm 4.2$ years) volunteered to participate current study. Those athletes were training and competing in a broad variety of sports and had different levels of competing experience. The participants were chosen from 20 different sports -8 team sports and 12 individual sports- including soccer, basketball, volleyball, handball, track and field, tennis and badminton.

\section{Measuring Instrument}

The SMTQ (Sheard et al., 2009) is a 14-item instrument was established to ascertain athletes' mental toughness levels. SMTQ items were constituted by using raw data themes and quotes from qualitative studies of mental toughness those were made previously. The participants had to respond to items on a four point Likert-type scale ranging from "not at all true" [1] to "very true" [4]. Sample items included "I interpret threats as positive opportunities" (confidence); "I give up in difficult situations" (constancy); and "I am overcome by self-doubt" (control). SMTQ has three sub-dimensions: 6 items for confidence $(\alpha=.80), 4$ items for constancy $(\alpha=.74)$, and 4 items for control $(\alpha=.71)$. Confidence sub-dimension assesses athletes' belief in their own abilities to achieve goals and be better than others. Constancy reflects determination, individual responsibility, an unyielding attitude, and ability to concentrate. Lastly, control sub-dimension is concerned with the perception that one is personally influential and can bring about desired outcomes with particular reference to controlling emotions (Sheard, 2010).

\section{Procedure}

Following ethical approval being obtained from a University Research Ethics Committee, volunteers were sought from sport clubs, with initial contact made by the author. Implied consent was obtained when the participants volunteered to complete and return the SMTQ questionnaire to the researchers. Because the main language spoken among students in Turkey is Turkish, we translated the SMTQ from the original English version to Turkish. The academicians who experts at English language forward-translated the English version into Turkish language and then another language experts who was bilingual back-translated the Turkish version to English. The forward and backward translation process was based on the principle of retaining meaning, rather than on literal word-to-word translation. Then, any deviations between the two translated versions were noted and the preliminary version of SMTQ was constructed. We invited three academicians with expertise in the areas of physical education \& sport sciences, sport psychology and psychometrics to review the content of the preliminary SMTQ version to make sure that the questions were culturally appropriate to the Turkish sports people.

Author applied a cross-sectional study design in this study. Participants' who volunteered to participate in the study completed the demographic questions and the SMTQ. The measurement was conducted over 2 months of period in 2016 February - March. Author distributed 375 questionnaires to the athletes; 350 were returned to the researcher, with a response rate of 93.3\%. However, after excluding 13 questionnaires with incomplete answers, there were 337 usable questionnaires. 


\section{Statistical Analysis}

Confirmatory Factor Analysis (CFA) was conducted by Analysis Moments of Structures (AMOS) 18. Comparative fit index (CFI) (CFI > 0.90, acceptable), non-normed fit index (NNFI) (NNFI $>0.90$ acceptable) (Maruyama, 1998) and root mean square error of approximation (RMSEA) (RMSEA <0.08, adequate model fit) (Jaccard \& Wann, 1996) were used to check if the model fit the data. Cronbach's Coefficient Alpha was computed to check for the internal consistency of adapted scale. Following Threshold Levels were used in order to prove model fits (Öcal, 2011). The measurement model based on the fit indices was evaluated for construct validity. For discriminant validity, Kline (2011) suggested that if the correlations between latent variables are less than 0.85 , discriminant validity can be established.

\section{RESULTS}

It was used CFA in order to test the factor structure that shows the sub-dimensions of Sport Mental Toughness questionnaire over the data gathered from athletes. Firstly, for a model with three factors (confidence, constancy and control) set in the original sub-dimension, goodness of fit (GOF) statistics were figured out. As a result of the analysis, $\chi^{2}(\mathrm{df}=101, p=.00)=354$, $\chi^{2} / \mathrm{df}=3.49$, RMSEA (Root Mean Square Error of Approximation) $=.182$, CFI (Comparative Fit Index $)=0.87$, NNFI $($ Non-Normed Fit Index $)=.86$ pointed out that the model were not fit with the expected level. Furthermore modification indices were checked and the pairs with high error covariances were connected (item 2, item 4 (control sub-dimension) and item 6, item 14 (confidence sub-dimension)) and the model has been revised again. The second CFA results were as $\chi^{2}(\mathrm{df}=72, \mathrm{p}=.00)=105, \chi^{2} / \mathrm{df}=1.46$, RMSEA (Root Mean Square Error of Approximation $)=$ .074 , CFI (Comparative Fit Index) $=.90$, NNFI (Non-Normed Fit Index $)=.90$ pointed out that the model is coherent at a satisfactory level. 


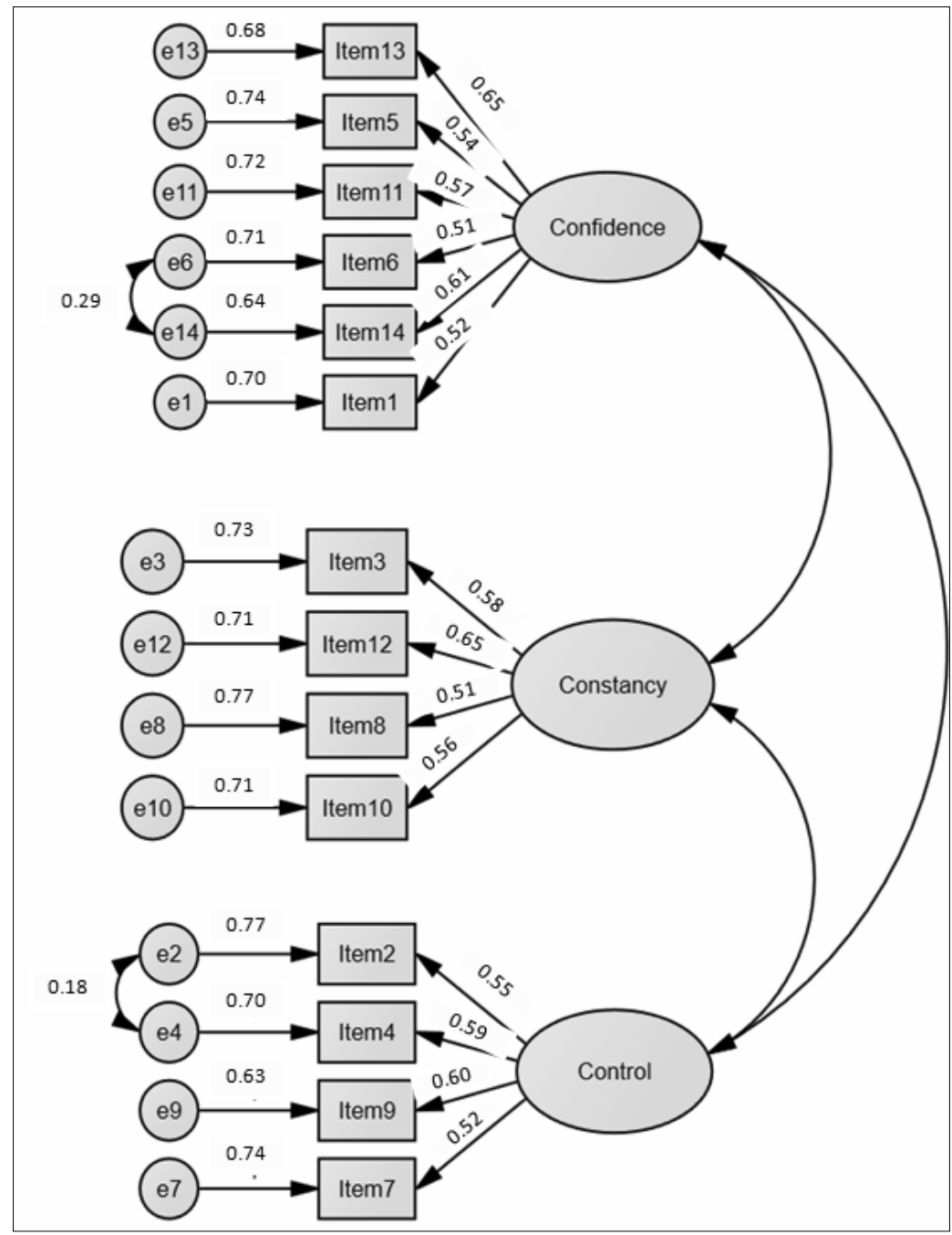

Fig. 1: Factor loadings of Latent Variables in the Model for SMTQ

To estimate the reliability level of competition sub-dimension The Cronbach's alpha was used. Separately the Cronbach's alpha level of each subscale and the overall of SMTQ values were obtained. According to results reported in the table below, the Cronbach's alpha coefficient for each variable is equal or greater than .69 (confidence $=.78$, constancy $=.75$ and control $=.69$ ) and the Cronbach's alpha coefficient of SMTQ was .82. Moreover, Analysis of "if item deleted" results did not yield any improvements.

Tab. 1: Cronbach's Alpha coefficient values of the SMTQ

\begin{tabular}{|c|c|c|c|}
\hline Values & No of Items & Items & Subscales \\
\hline .78 & 6 & $1,5,6,11,13,14$ & Confidence \\
\hline .75 & 4 & $3,8,10,12$ & Constancy \\
\hline .69 & 4 & $2,4,7,9$ & Control \\
\hline .82 & 14 & 3 subscales & Total alpha of SMTQ \\
\hline
\end{tabular}


The mean points taken from the sport mental toughness questionnaire sub-dimensions were 39.78 $(\mathrm{S}=5.10)$ for total, $16.16(\mathrm{~S}=3.10)$ for Confidence subscale, $12.58(\mathrm{~S}=2.60)$ for Constancy Subscale and $10.35(\mathrm{~S}=2.27)$ for Control subscale.

The discriminant validity was checked based on the correlations among the latent variables. Table 2 presents the Pearson's product-moment correlation value and its significant indication. All correlations were below the recommended cut-off point of 0.85 , which indicated that the eight-motive latent variables achieved good discriminant validity.

Tab. 2: Correlations Between Latent Variables in the Model for SMTQ

\begin{tabular}{|c|c|c|c|}
\hline Variable & Confidence & Constancy & Control \\
\hline Confidence & - & $.271^{*}$ & $.345^{*}$ \\
\hline Constancy & & - & $.424^{*}$ \\
\hline Control & & & - \\
\hline
\end{tabular}

Note. ${ }^{*}$ Correlation is significant at the 0.05 level (two-tailed)

\section{DISCUSSION}

The goal of the study was to evaluate the psychometric properties of the Sport Mental Toughness Questionnaire (SMTQ) (Sheard, Golby, \& van Wersch, 2009) on Turkish population. In this study, the confirmatory factor analysis was used and the data collected from 337 athletes from 20 different sports. Confirmatory factor analysis results supported the initial structure of the inventory for the overall model.

A multitude of measures has been proposed to measure mental toughness in sport. As mentioned before several general (Psychological Performance Inventory, (PPI); Psychological Performance Inventory-Alternative, (PPI-A); Mental Toughness Questionnaire, (MTQ-48) and Inventory of Mental Toughness (IoMT) instruments have been employed in the literature. However, none of these measures purporting to examine mental toughness have satisfied all the rigorous construct validation principles deemed necessary for the development of sound instrumentation (Sheard, Golby, \& van Wersch, 2009). For example, a measure may display satisfactory factorial validity, but lack face or external validity. Even when validity criteria have been satisfied, a measure that is not grounded in theory may fail to adequately inform researchers why particular components are included (or not) in the measure. Given the shortage of present measurements in the sport domain current literature the Sport Mental Toughness was selected for utilize in our research based on its item convenience (14-items), empirical application, and factorial validity.

In an original study Sheard et al., collected data from 509 athletes to develop and evaluate psychometric properties of SMTQ in 2009. In their findings, it is indicated a good model fit: $\chi_{(74, N=509)}^{2}=182.56, p<.01, \chi^{2} / d f=2.47$, goodness-of fit index $(\mathrm{GFI})=.95$, adjusted goodness-of-fit index $(\mathrm{AGFI})=.93$, root-mean-square error of approximation RMSEA $=.05$, root-mean-square residual $(\mathrm{RMR})=.05$. Also, the incremental fit indices indicated good support for the model: $\mathrm{TLI}=.91, \mathrm{CFI}=.92$, IFI $=.93$. Moreover, the three factors' intercorrelations were all positive and statistically significant $(p<.01)$ : Confidence $\cdot$ Constancy $=.31$; Confidence $\cdot$ Control $=.28$; and Constancy $\cdot$ Control $=.32$. These results supported our findings.

Consistent with our findings, Kashani et al. (2015) have tried to evaluate psychometric properties Persian version of SMTQ. In their study, results showed that SMTQ had acceptable fit index $(\mathrm{RMSEA}=0.06, \mathrm{CFI}=0.94, \mathrm{TLI}=0.92)$, internal consistency $($ Confidence $=0.76$, Constancy $=0.78$, Control $=0.72$, and the total $=0.76)$, and temporal reliability $($ Confidence $=0.74$, Con- 
stancy $=0.82$, Control $=0.74$, and the total $=0.83$, indicating good validity and reliability of the Persian version of SMTQ.

CFA results indicate a good model fit as those reported previously. In particular, the absolute fit index used, RMSEA demonstrate a very good model fit in all samples. Considering the range of fit indices from CFA and NNFI and taking into account the breadth and depth of the sample used, the SMTQ is a robust psychometric instrument.

\section{CONCLUSION}

Mental toughness in athletes is one of the most popular research topics in sport psychology and interest in the topic continues to grow. The present results' of the Sport Mental Toughness Questionnaire- Turkish version has quite strong psychometric properties. In other saying, SMTQTurkish version is a valid and reliable test instrument to evaluate mental toughness levels of Turkish sports contexts (athletes, coaches, referees etc.).

The findings from this study can suggest potential recommendations for future researches. Initially, several proposed measures are available, yet none have adequately conceptualized the construct, been validated through statistical procedures, and been brief enough to accommodate use in real sport settings. Thus, continued evaluation of the SMTQ is necessary. After that, there should be more studies those aim to examine the relationship between mental toughness and other variables. Include performance, learning level, gender differences, performance strategies, psychological skills and etc.

\section{References}

Bull, S. J., Shambrook, C. J., James, W., \& Brooks, J. E. (2005). Towards an understanding of mental toughness in elite English cricketers. Journal of Applied Sport Psychology, 17(3), 209-227.

Clough, P. J., Earle, K., \& Sewell, D. (2002). Mental toughness: the concept and its measurement. In I. Cockerill (Ed.). Solutions in sport psychology (p. 32-43). London: Thomson.

Coulter, T. J., Mallett, C. J., \& Gucciardi, D. F. (2010). Understanding mental toughness in Australian soccer: Perceptions of players, parents, and coaches. Journal of Sport Sciences, 28, 699-716.

Crust, L. (2008). A review and conceptual re-examination of mental toughness: Implications for future researchers. Personality and Individual Differences, 45, 576-583.

Golby, J., Sheard, M., \& van Wersch, A. (2007). Evaluating the factor structure of the Psychological Performance Inventory (PPI). Perceptual and Motor Skills; 105, 309-325.

Golby, J., \& Sheard, M., (2004). Mental toughness and hardiness at different levels of rugby league. Personality and Individual Differences, 37, 933-942.

Gould, D., Dieffenbach, K., \& Moffett, A. (2002). Psychological characteristics and their development in Olympic champions. Journal of Applied Sport Psychology, 14, 172-204.

Gucciardi, D. F., Jackson, B., Hodge, K., Anthony, D. R., \& Brooke, L. E. (2015). Implicit Theories of Mental Toughness: Relations with Cognitive, Motivational, and Behavioral Correlates. Sport, Exercise and Performance Psychology, 4, 100-112.

Gucciardi, D. F, Gordon S., Dimmock, J. A. (2009). Evaluation of a mental toughness training program for youth-aged Australian footballers: I. A quantitative analysis. Journal of Applied Sport Psychology, 21, 307-323.

Jaccard, J., \& Wann, C. K. (1996). LISREL approaches to interaction effects in multiple regression. Thousand Oaks, CA: Sage Publications.

Kline, R. B. (2011). Principles and practice of structural equation modeling (3rd ed.). New York: The Guilford Press.

Loehr, J. E. (1996). Mental toughness training for sports: Achieving athletic excellence. Lexington, MA: Stephen Greene Press. Maruyama, G. M. (1998). Basics of structural equation modeling. Thousand Oaks, Ca: Sage.

Middleton, C. S, Martin, A. J, \& Marsh, H. (2011). Development and validation of the mental toughness inventory: a construct validation approach. In D. F. Gucciardi, S. Gordon (Ed.). Mental toughness in Sports: Developments in theory and research (p. 91-107). 1st ed. New York, NY: Routledge.

Newland, A., Newton, M., Finch, L., Harbke, C. R., \& Podlog, L. (2013). Moderating variables in the relationship between mental toughness and performance in basketball. Journal of Sport and Health Science, 2, 184-192. 
Öcal, K. (2011). Predicting Employee Performance in Non-Profit Sport Organizations: The Role of Managerial and Financial Performance and the Mediating Role of Support for Innovation and Individual Creativity. Unpublished doctoral dissertation, Middle East Technical University, Turkey.

Sheard, M., \& Golby, J. (2006a). Effect of a psychological skills training program on swimming performance and positive psychological development. International Journal of Sport and Exercise Psychology, 4, 149-169.

Sheard, M., Golby, J., \& van Wersch, A. (2009). Progress toward construct validation of the Sports Mental Toughness Questionnaire (SMTQ). European Journal of Psychological Assessment, 25(3), 186-193.

Sheard, M. (2010). Mental toughness: The mindset behind sporting achievement. Hove, East Sussex. Routledge.

Thelwell, R., Weston, N., \& Greenlees, I. (2005). Defining and understanding mental toughness in soccer. Journal of Applied Sport Psychology, 17, 326-332.

\section{Corresponding Author:}

Bülent Okan Miçooğulları, PhD,

Physical Education \& Sports Department, Nevşehir Hacı Bektaş Veli University,Nevşehir-TURKEY.

okanmicoogullari@gmail.com \& omicoogullari@nevsehir.edu.tr 